\title{
STRATEGI PEMBELAJARAN AKSARA HAN PADA PEMBELAJARAN MANDARIN TINGKAT DASAR
}

\author{
Ina \\ Fakultas Keguruan dan Ilmu Kependidikan, Universitas Tanjungpura \\ Email:ina@fkip.untan.ac.id
}

\section{INFO ARTIKEL \\ Riwayat Artikel: \\ Menerima : 19 Nopember 2020 \\ Revisi : : 11 April 2021 \\ Diterima : 15 April 2021}

\section{Kata Kunci:}

Aksara Han, Strategi belajar, Bahasa Mandarin

Keywords:

Han character, learning strategy, Chinese

\section{Korespondensi:}

Ina

Universitas Tanjungpura

Email:

ina@fkip.untan.ac.id

\begin{abstract}
ABSTRAK
Aksara Han merupakan aksara yang dibentuk dari goresan atau komponen yang ditulis dengan urutan tertentu dan disusun secara simetris pada satu bidang persegi. Hal ini menyebabkan mahasiswa Indonesia yang telah terbiasa dengan huruf latin mengalami kesulitan dalam mempelajari aksara Han. Oleh karena itu, penting untuk mengetahui ketepatan strategi belajar aksara Han yang digunakan oleh mahasiswa, agar dosen dapat memberikan arahan dan bimbingan dalam pemilihan strategi belajar yang tepat. Penelitian ini merupakan penelitian kualitatif deskriptif dengan menggunakan kuesioner untuk mendata strategi belajar, sikap belajar dan kendala yang dihadapi saat belajar aksara Han serta upaya yang dilakukan untuk mengatasinya. Data penelitian diukur menggunakan skala likert 1-5 dan dianalisis secara deskriptif persentanse dengan hasil menunjukkan bahwa responden memiliki sikap positif dalam belajar, namun sebagian responden masih bergantung pada pengunaan pinyin, intensitas latihan belum maksimal dan tidak semua responden memanfaatkan karakteristik aksara Han untuk meningkatkan efektivitas dalam mengingat dan mempelajari penulisan, pelafalan dan arti aksara Han.
\end{abstract}

\section{ABSTRACT}

Han characters are characters formed from strokes or components that are written in a certain order and arranged symmetrically on one square. This causes Indonesian students who are accustomed to Latin letters to experience difficulty in learning Han characters. Therefore, it is important to know the accuracy of the Han characters learning strategies used by students, so that lecturers can provide direction and guidance in choosing the right learning strategy. This research is a descriptive qualitative study using a questionnaire to record learning strategies, learning attitudes, and obstacles faced when learning Han characters and the efforts made to overcome them. The research was measured using a Likert scale of 1-5 and analyzed by the percentage descriptive with the results showing that respondents have a positive attitude in learning, but some respondents still depend on the use of pinyin, the intensity of the exercise is not maximal and not all respondents take advantage of the characteristics of the Han characters to increase the effectiveness in remembering and learning the writing, pronunciation, and meaning of Han characters.

\section{PENDAHULUAN}

Huang, Borong (2014) mendefinisikan aksara Han sebagai suatu sistem yang berisi simbol-simbol yang digunakan untuk merekam bahasa. Aksara Han adalah simbol yang digunakan dalam bahasa tulisan untuk menvisualisasikan bahasa Mandarin. $80 \%$ aksara Han merupakan aksara phono-semantic compound yang memiliki kemampuan menyiratkan arti dan menyiratkan bunyi (pelafalan). Chen, Xi (2001) dan Hu, Wenhua (2008) serta Zhou, Jian (2009) memaparkan 
bahwa aksara Han yang paling tua yang ditemukan di kota An Yang, Provinsi Henan (1899) adalah aksara "jiaguwen /oracle" yang diukir pada cangkang kura-kura dan tulang belulang hewan buas. Pada saat penggunaan aksara tersebut, masyarakat pada saat yang itu juga menggunakan "skrip perunggu Ibronzeware script", yaitu tulisan yang dibuat dengan metode pengecoran pada wadah perunggu yang disebut ding (鼎). Kedua jenis tulisan ini digunakan masyarakat pada masa akhir dinasti Shang. Pada perkembangannya, kedua aksara ini berevolusi menjadi Aksara "Segel/Seal Script" dan "aksara regular/Clerical Script". Aksara Han yang dipergunakan pada saat ini adalah variasi dari "Aksara Reguler", yaitu font Simsun, FangSong dan Xingshu/semi-cursive script. Aksara Han yang dipergunakan sekarang ini merupakan revolusi dari jiaguwen, yaitu dari simbol gambar menjadi simbol dan goresan yang lebih sederhana, standar dan teratur.

Chen, Xi (2001) memaparkan teknik pembentukan dan penggunaan aksara Han adalah Liushu, yang terdiri dari piktogram, deogram, compound ideographs, phonosemantic compound, rebus (phonetic loan) dan derivative cognates. Sebuah aksara disusun dari satu atau lebih goresan (bihua), yang kemudian dituliskan dalam satu bidang persegi dengan urutan penulisan tertentu (bishun) dan menggunakan struktur (jieguo) aksara tertentu.

Li, Xiangping (2012) mendefinisikan goresan sebagai unsur pembentuk aksara Han yang paling mendasar, yang juga merupakan unsur tulisan bahasa Mandarin. Wang,
Xiurong (2013) mendefinisikan goresan sebagai unsur terkecil dalam sebuah aksara Han. Zhou, Jian (2009) mendefinisikan goresan/bihua sebagai garis-garis dengan bentuk berbeda yang merupakan komponen terkecil dari aksara Han. Goresan dibagi menjadi goresan dasar (basic strokes) dan goresan gabungan (compound strokes). Delapan goresan dasar aksara Han terdiri dari - ( héng ), I ( shù ), J ( piě ), l ( nà ) 、 ( diăn ), ノ ( tí ), J ( gōu ), ᄀ ( zhé ) . Huang, Borong, dkk (2014) menyatakan bahwa goresan dapat dibagi menjadi goresan utama dan goresan tambahan. Goresan utama adalah cara menulis goresan pada umumnya, sedangkan goresan tambahan adalah cara menulis goresan yang mengalami perubahan sesuai dengan posisi goresan tersebut dalam aksara Han. Huang menyebutkan tujuh jenis goresan tunggal dan 1 goresan gabungan, yaitu (héngzhé). Zhou, Jian (2009) mendefinisikan urutan penulisan/bishun sebagai urutan penulisan goresan saat mulai menulis suatu aksara, dimana urutan penulisan ini merupakan rangkuman pengalaman orangorang dalam menulis aksara Han secara benar dengan menggunakan maobi/kuas. Li, Xiangping (2012) mendefinisikan urutan penulisan/bishun sebagai urutan penulisan aksara Han yang dimulai dengan penentuan dari mana awal penulisan goresan dan kemudian diikuti dengan penentuan goresan mana yang dituliskan. Jadi dapat kita simpulkan bahwa urutan penulisan/bihua merupakan aturan urutan penulisan goresan 
dalam menulis suatu aksara Han mulai dari penentuan goresan pertama, goresan kedua, sampai dengan aksara tersebut selesai ditulis, sesuai dengan kelaziman yang telah berlaku umum. $\quad \mathrm{Li}, \quad$ Xiangping mengelompokkan bishun menjadi tujuh aturan dasar dan empat aturan tambahan. Aturan dasar menulis terdiri dari (1) Menulis kemudian I; (2) Menulis J kemudian \; (3) Dari atas ke bawah; (4) Dari kiri ke kanan; (5) Dari luar ke dalam; (6) Dari luar ke dalam, kemudian ditutup; serta (7) Dari tengah ke samping kiri dan kanan. Aturan urutan penulisan tambahan terdiri dari: (1) Jika 、 berada di sebelah kiri atas, maka ditulis terlebih dahulu; Jika 、 berada di sebelah kanan atas, maka ditulis belakangan; Jika 、 berada di dalam, maka ditulis belakangan; (2) Jika - berada diatas dan | di sebelah kiri, atau berada pada struktur $\square$ dan $\square$, maka ditulis terlebih dahulu. (3) Aksara Han dengan struktur tertutup di 2 bagian $\square$, penulisan aksara dimulai dari bagian dalam ke luar; Jika jumlah goresan aksara Han tersebut banyak, maka urutan penulisan dimulai dari bagian luar ke dalam; Aksara Han dengan struktur dan G, di tulis mulai dari bagian luar ke dalam. (4) Aksara Han dengan struktur tertutup 3 bagian, ditulis dengan ketentuan jika bagian yang terbuka menghadap atas, maka penulisan dimulai dari bagian dalam ke luar; Jika bagian yang terbuka menghadap kanan, biasanya penulisan ditulis dari atas ke dalam, kemudian baru menulis bagian kanan dan bawah. Huang, Borong, dkk (2014) menjelaskan bahwa kebanyakan aksara Han tidak ditulis dengan aturan sederhana dari atas ke bawah, dan dari kiri ke kanan, namun merupakan kombinasi dari aturan urutan penulisan yang ada. Dijelaskan pula bahwa aksara Han merupakan fangkuai zi/block character, yang secara harfiah diartikan menjadi huruf berbentuk kotak. Aksara Han merupakan aksara yang dibentuk dari goresan atau komponen yang ditulis dengan urutan tertentu dan disusun secara simetris pada satu bidang persegi.

Hu, Wenhua (2008) menyatakan bahwa komponen/bujian adalah struktur aksara yang diperoleh setelah membagi aksara tersebut menjadi satu atau beberapa bagian sesuai dengan fungsinya dan biasanya komponen/bujian lebih besar dari goresan. Aksara Han dapat dibedakan dalam kategori tunggal dan gabungan. Aksara dengan komponen gabungan misalnya aksara 和 , terdiri dari komponen 禾 dan 口; aksara 涨 tediri dari komponen $\dot{y}$ dan 张, dan 张 terdiri dari komponen 弓 dan 长. Dalam penelitiannya terhadap 800 aksara level 1 Daftar Aksara dan Kosakata Bahasa Mandarin, diperoleh hasil bahwa ada 24,4\% (194) aksara Han merupakan aksara tunggal. Pengklasifikasian struktur (jiegou) aksara Han dapat dipaparkan sebagai berikut: struktur atas bawah misalnya aksara 思, struktur atas, tengah dan bawah misalnya aksara 曼, struktur kiri kanan misalnya aksara 休, struktur tutup 4 sisi misalnya aksara 国, struktur tutup 2 sisi misalnya aksara 庞 dan 可, struktur tutup 3 sisi 
misalnya aksara 同 dan 凶， struktur berpotongan misalnya aksara 乘 dan struktur aksara 品 misalnya aksara 森.

Ke, Chuanren (2018) dalam penelitiannya merangkum beberapa penelitian yang telah dilakukan dalam bidang belajar dan mengajar bahasa Mandarin sebagai bahasa kedua sejak berdirinya Chinese Language Teacher Association pada tahun 1962. Penelitian yang dilakukan oleh Huang, Jinjin (2000) terhadap 44 siswa berkebangsaan Jerman dengan kemampuan berbahasa Mandarin tingkat dasar satu 18 siswa, tingkat dasar dua 1 siswa, tingkat menengah 18 siswa dan tingkat lanjutan 7 siswa, dengan menggunakan kuesioner dan metode tes menunjukkan hasil bahwa strategi yang paling sering digunakan adalah menulis (60\%), menggunakan kartu aksara (21\%) dan membongkar aksara (19\%). Penelitian yang dilakukan oleh Jiang, Xin \& Zhao, Guo (2001) terhadap siswa program foundation (Mandarin Dasar) Beijing Language and Culture University yang mempunyai latar belakang budaya yang berbeda-beda dan pengalaman belajar bahasa Mandarin selama 4-9 bulan, dengan menggunakan kuesioner menunjukkan bahwa strategi yang paling sering digunakan adalah mengingat aksara sebagai satu kesatuan, pelafalan dan arti, mengingat goresan, dan mengulang; Strategi yang kurang sering digunakan adalah strategi praktek/pengunaan. Selain itu diketahui pula bahwa siswa yang bahasa ibunya sinophone dengan bahasa Mandarin lebih sering menggunakan strategi pelafalan, arti dan praktek/penggunaan.
Penelitian sejenis dilakukan oleh Sung, Koyin \& Wu, Hsiao Ping (2011) terhadap 108 siswa pelajar bahasa Mandarin pemula di State University, USA, yang rata-rata berusia 20 tahun, dengan menggunakan kuesioner Shen's (2005) "The Character Learning Strategies Inventory" . Data diolah dengan menggunakan SPSS, dengan hasil menunjukkan bahwa strategi pembelajaran aksara Han yang paling lazim dipergunakan adalah berlatih, asosiasi/menghubungkan, memperhatikan karakteristik aksara, menggunakan teknik mekanik, pengelompokkan dan memperhatikan pelafalan. Temuan kedua dari penelitian ini adalah terdapat perbedaan strategi yang dipergunakan berdasarkan latar belakang gender, latar belakang suku bangsa dan pengalaman belajar bahasa asing.

\section{METODE PENELITIAN}

Penelitian dilakukan dengan metode kualitatif deskriptif dengan menggunakan kuesioner yang meliputi pertanyaan mengenai kemampuan dalam penguasaan aksara Han, strategi yang dipergunakan dalam mempelajari aksara Han, kendala yang dihadapi dan usaha yang dilakukan oleh mahasiwa responden untuk mengatasinya. Data penelitian yang diperoleh dari kuesioner, diukur menggunakan skala likert 1-5 dan dianalisis secara deskriptif persentanse. Obyek penelitian ini adalah mahasiswa angkatan 2019 Program Studi Pendidikan Bahasa Mandarin Fakultas Keguruan dan Ilmu Pendidikan Universitas Tanjungpura sejumlah 31 mahasiswa. Responden memiliki kemampuan berbahasa Mandarin yang diukur dengan Chinese 
Profiency Test/HSK yaitu HSK2 3\%, HSK3 $10 \%$, HSK $46 \%$ dan $81 \%$ belum pernah mengikuti tes HSK. Lama pengalaman belajar responden, yaitu: <1 tahun sebanyak 48,4\%, 12 tahun sebanyak $16,1 \%, 2-3$ tahun sebanyak $3,2 \%$ dan $>3$ tahun sebanyak 32,3\%. Dilihat dari suku bangsanya, $57 \%$ responden mempunyai latar belakang suku bangsa Non Tionghoa dan $43 \%$ responden berlatar belakang suku Tionghoa.

\section{HASIL DAN PEMBAHASAN}

Mahasiswa responden merupakan mahasiswa Program Studi Pendidikan Bahasa Mandarin FKIP Universitas Tanjungpura Angkatan 2019 (semester tiga). 87,1\% responden belajar bahasa Mandarin karena menganggap bahasa Mandarin sangat membantu di masa yang akan datang dalam mendapatkan pekerjaan. Kesulitan dalam mengingat, melafalkan, menulis dan memahami arti aksara Han menjadi kesulitan di nomor urut ketiga setelah kesulitan dalam pelafalan dan penguasaan kosakata bahasa Mandarin. Oleh karena itu, 35,5\% responden masih memerlukan bantuan Hanyu Pinyin untuk membaca aksara Han.

\section{Strategi Pembelajaran Aksara Han}

Berdasarkan hasil penelitian diketahui beberapa strategi yang lazim digunakan dalam mempelajari aksara Han meliputi (a) Menuliskan kembali aksara yang dipelajari berulang-ulang; (b) Menghafalkan saja tanpa menuliskan aksara yang dipelajari; (c) Mengingat urutan penulisan aksara; (d)
Mengingat berdasarkan komponen aksara; (e) Mengingat berdasarkan radikal aksara dan (f) Belajar dari aplikasi setiap ada kesempatan. Berdasarkan tabulasi data kuesioner diketahui bahwa $83,87 \%$ responden menggunakan kombinasi 6 strategi diatas untuk belajar aksara Han, dan hanya ada sedikit responden yang hanya mengunakan satu atau kurang dari enam strategi untuk belajar aksara Han

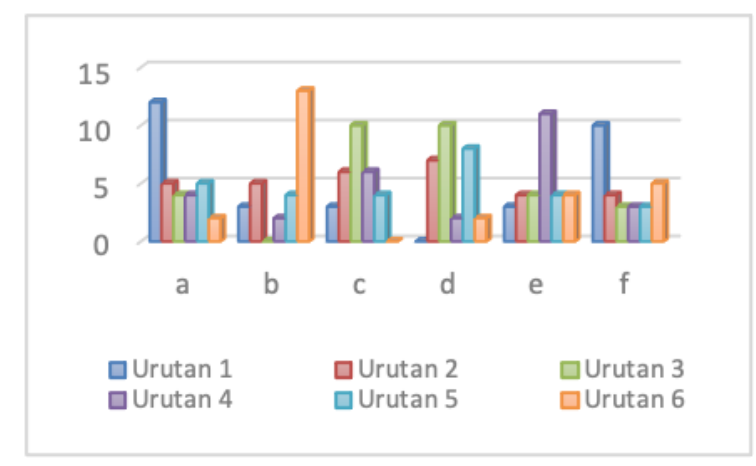
Gambar 1. Urutan Penggunaan Strategi
Belajar Aksara Han

Strategi belajar aksara Han secara berurutan dari yang paling lazim dipergunakan adalah (a) Menuliskan kembali aksara berulang-ulang; yang kedua adalah (f) Belajar dengan menggunakan aplikasi; yang ketiga adalah (c) Mengingat urutan penulisan dan (d) Mengingat berdasarkan komponen aksara; yang keempat adalah (e) Mengingat aksara berdasarkan radikal. Sedangkan strategi belajar yang paling tidak lazim digunakan adalah (b) Hanya menghafalkan aksara yang dipelajari tanpa menuliskan kembali.

Hasil penelitian ini menunjukkan adanya kesamaan strategi pembelajaran yang dilakukan oleh pelajar bahasa Mandarin. Sebagaimana hasil penelitian yang dilakukan oleh Huang, Jinjin (2000) bahwa strategi yang paling lazim dilakukan adalah menulis. 
Penelitian Sung, Koyin \& Wu, Hsiao Ping (2011) mendapatkan hasil bahwa strategi belajar aksara Han yang menempati urutan pertama adalah berlatih. Hal ini sesuai dengan tuntutan teori belajar aksara Han yang dikemukakan oleh Chen, Xuechao (2011) bahwa untuk menguasai aksara Han perlu latihan secara berulang-ulang dalam jangka waktu panjang.

\section{Kemampuan Mengenal, Menulis dan Memahami Arti Aksara Han}

Hasil penelitian menunjukkan hasil bahwa 51,62\% responden menyatakan mereka telah memahami jenis-jenis goresan dalam aksara Han dan $61,29 \%$ responden menyatakan mampu menulis aksara Han sesuai dengan goresannya. Namun, 16,12\% responden sangat setuju dan $35,48 \%$ responden setuju bahwa semakin lama mereka belajar, mereka merasa aksara Han semakin sulit dipelajari.

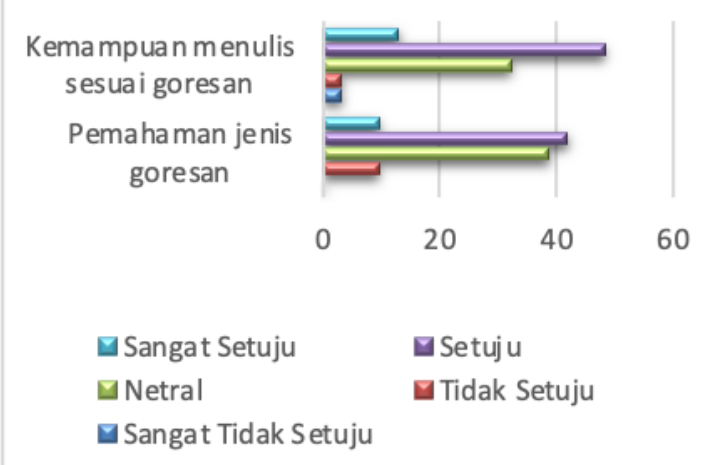

Gambar 2. Kemampuan Menulis Aksara Han

Chi, Lanying (2015) menyatakan bahwa jumlah pelajar bahasa Mandarin mempunyai model piramida emas, dimana jumlah pelajar di level yang lebih tinggi lebih sedikit dibandingkan dengan level sebelumnya, dan
$50 \%$ pelajar yang mempelajari bahasa Mandarin berhenti di semester ke-2 atau di tahun ke-2 karena merasa aksara Han sulit dibedakan, sulit ditulis dan sulit diingat.

Kemampuan kognitif responden dalam mengingat aksara Han cukup baik, 74,19\% responden dapat secara langsung mendapatkan gambaran aksara yang sedang didiktekan oleh dosen. Hal ini berarti dalam sistem bahasa responden terdapat aturan dan sistematika penulisan aksara Han. Chen, Xuechao (2009) memaparkan 5 buah prinsip pengajaran aksara Han, diantaranya adalah pemahaman struktur aksara Han (jiegou) dan aturan penulisan, pemanfaatan Liushu (teknik pembentukan aksara Han) untuk membantu siswa mempelajari aksara han serta memaksimalkan intensitas menulis dan latihan, agar waktu yang digunakan siswa untuk menguasai aksara Han lebih efektif dan efisien.

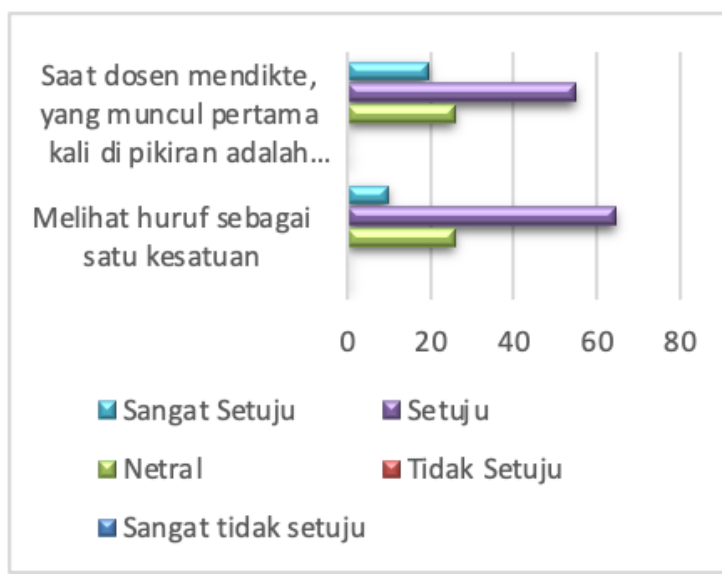

Gambar 3. Kemampuan Responden Mengenal Aksara Han

Selain itu, hasil penelitian juga menunjukkan $74,2 \%$ responden mengenal aksara Han sebagai suatu kesatuan. Aksara Han yang dibentuk dari komponen tunggal disusun dari satu atau lebih goresan, misalnya aksara 大(dà) yang berarti "besar", disusun 
dari tiga goresan yaitu 一ノ、. Sedangkan aksara yang dibentuk dari komponen gabungan misalnya aksara 相 (xiāng ) yang berarti “saling”, disusun dari komponen 木 dan 目. Dilihat dari goresannya, aksara 相 terdiri 9 goresan, yaitu $-1, 、 17$ Oleh karena itu, akan lebih mudah mengingat aksara 相 jika responden mempelajarinya sebagai gabungan dari komponen 木 dan 目, dibandingkan jika aksara ini dianggap sebagai gabungan dari beberapa goresan. Chen, Xuechao (2011) menyatakan bahwa menulis aksara Han mempunyai aturannya sendiri, mulai dari aturan menuliskan goresan, mengabungkan dua goresan tunggal, dimana posisi radikal dan komposisi komponen huruf. Li, Xiangping (2012) menjelaskan pula bahwa komponen aksara Han merupakan unsur penting dalam pembentukan aksara Han, yang bermanfaat untuk memudahkan siswa membedakan dan membaca aksara Han.

\section{Perilaku Belajar Responden}

Beberapa kondisi yang tergambar dari perilaku responden dalam mempelajari aksara Han yang didapatkan dalam penelitian ini adalah adanya usaha dari responden untuk mencari bantuan dan bertanya pada saat mengalami kesulitan atau menemukan aksara baru. $\quad 93,55 \%$ responden senantiasa memperhatikan dengan cermat saat dosen mendemonstrasikan cara penulisan suatu aksara dan $80,64 \%$ responden berusaha menyimak sambil melihat teks/subtitle saat menonton film. Namun, ditinjau dari segi intensitas latihan menulis responden, frekuensi belajar perlu ditingkatkan, karena hanya ada $32,26 \%$ responden telaten dalam melakukan latihan dan masih ada $38,71 \%$ responden yang belajar saat akan dilakukan dikte/tingxie saja. Selain itu, ketergantungan responden pada pinyin dalam mempelajari aksara Han masih tinggi. Hal ini terlihat dari jumlah responden yang selalu mencatat dengan menggunakan aksara Han hanya sebesar 22,58\%.

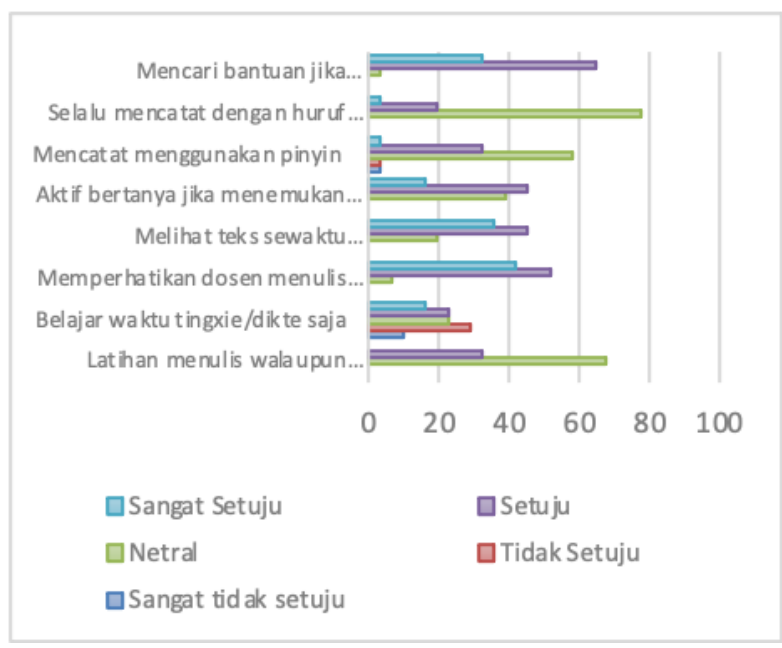

Gambar 4. Perilaku Responden Dalam Belajar

Huang Weijia (2011) menjelaskan bahwa untuk dapat menulis aksara Han dengan benar diperlukan ketelitian dan ketelatenan, terutama pada tingkat dasar. Saat baru belajar, penulisan aksara Han harus dilakukan sesuai dengan buku panduan atau kamus dan dituliskan goresan demi goresan dengan tepat, terutama pada aksara atau goresan yang memiliki kesamaan. Zhao, Guo \& Jiang, Xin (2002) dalam penelitiannya menyimpulkan ada 2 strategi yang efektif dalam mempelajari aksara Han, yaitu mengaplikasikan aksara Han dalam kegiatan membaca dan menulis, mempelajari radikal, dan menggunakan karakteristik huruf piktograf. Sedangkan menghafalkan aksara 
dan menuliskan kembali secara mekanis tanpa mengetahui arti aksara tersebut dinilai sangat tidak efektif dalam pembelajaran aksara Han.

\section{Upaya dan Persepsi Dalam Belajar} Aksara Han

Hasil penelitian menunjukkan bahwa reponden memiliki sikap belajar yang positif, yang diketahui dari kemauan responden untuk memeriksa kembali aksara Han yang ditulisnya dan memperbaiki kesalahan penulisan apabila ditemukan kesalahan penulisan. $77,42 \%$ responden memeriksa kembali aksara yang telah ditulisnya dan memperbaiki kesalahan penulisan aksara yang ditemukan.

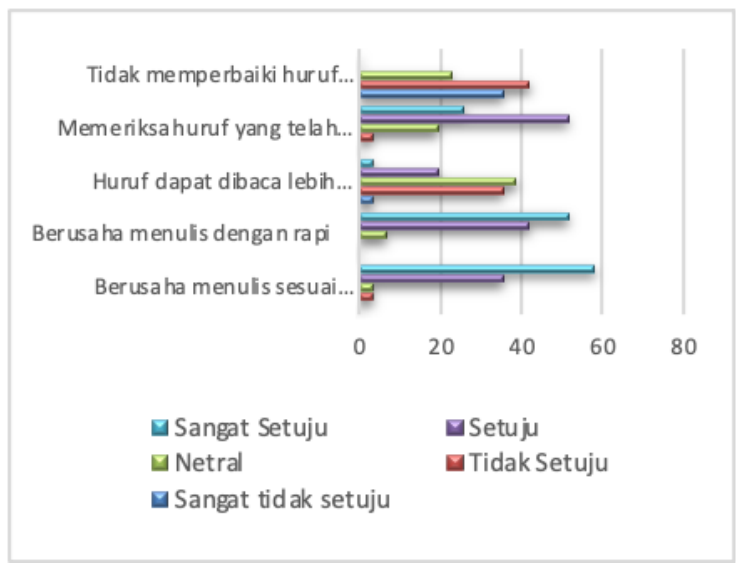

Gambar 5. Upaya dan Persepsi Dalam Belajar Aksara Han

Berdasarkan hasil analisis kuesioner diketahui bahwa 93,54\% responden berusaha menulis aksara Han sesuai dengan urutannya dan $93,55 \%$ responden berusaha menuliskan aksara dengan rapi. Namun, sebagian responden masih menganggap asalkan aksara tersebut dapat dibaca, kerapian penulisan aksara dapat diabaikan. Chen, Xuechao (2011) menuliskan bahwa urutan penulisan goresan merupakan aturan dalam urutan menulis aksara Han. Guru perlu memberikan pemahaman kepada siswa bahwa menulis sesuai dengan urutan goresan dapat mengefisienkan waktu yang digunakan untuk menulis aksara Han, menghasilkan tulisan aksara Han yang indah dan secara keseluruhan meningkatkan kemampuan siswa dalam menulis aksara Han. Bie, Hongying, dkk (2018) memaparkan pula lima prinsip dalam pembelajaran aksara Han, diantaranya adalah menguasai konsep dasar pembentukan aksara Han serta memanfaatkan kemampuan aksara Han dapat menyiratkan bunyi dan menyiratkan arti untuk meningkatkan daya ingat, pembelajaran aksara Han mencakup serta memperhatikan goresan, urutan penulisan, komponen dan struktur aksara Han, dan mengutamakan perbandingan, memperbanyak mengulang serta meningkatkan kemampuan membedakan dan menulis aksara Han melalui latihan menulis.

\section{Strategi Belajar Aksara Baru}

Dalam penelitian ini diketahui bahwa strategi yang digunakan responden dalam mempelajari aksara baru adalah 45,16\% responden menggunakan strategi mengulang dan menghafal, $16,13 \%$ responden menggunakan strategi membaca, menulis dan mengingat-ingat aksara tersebut secara berulang-ulang. Strategi yang dilakukan responden dalam mengulang dan menghafal adalah mengulang materi di buku, mencari video tutorial, mencatat, latihan membaca, menuliskan secara berulang-ulang, memperhatikan dan merangkum perbedaan 
antara dua aksara yang bentuk atau pelafalannya mirip, menghafal sesuai dengan urutan aksara, mengingat radikal dan goresannya dan mencari dahulu artinya baru menghafalkan aksara.

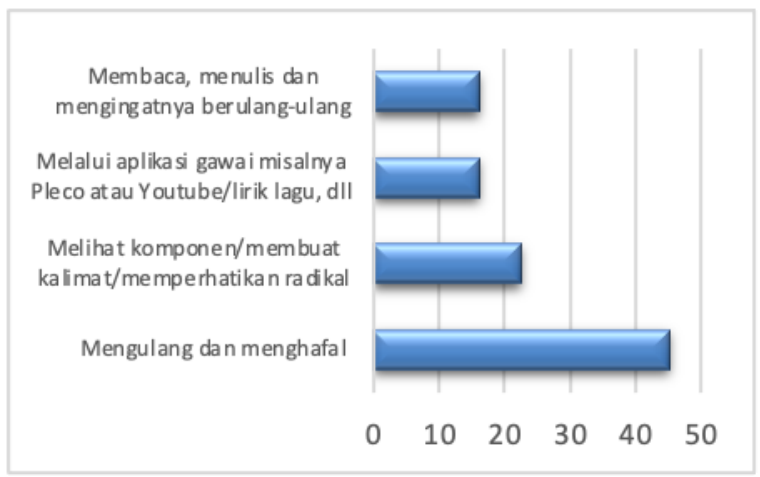

Gambar 6. Strategi Belajar Aksara Baru

Penelitian yang dilakukan Gao, Xiaoping (2020) menunjukkan strategi dalam menguasai penulisan aksara Han yang paling lazim digunakan adalah menulis berulang-ulang (68\%), menggunakan media (misalnya lembaran huruf) untuk mengingat (20\%), menggunakan flashcard dan menganalisa struktur aksara (10\%) dan tidak menggunakan strategi (3\%). Untuk menguasai cara membaca aksara Han, siswa responden menggunakan latihan membaca, membaca nyaring dan menulis secara berulang-ulang (63\%), menulis dan dibaca (20\%), membaca dan menghafal dari berbagai media ajar (8\%), mempelajari radikal, tata bahasa dan quiz (8\%) dan $3 \%$ menyatakan tidak mengetahui dengan jelas strategi yang dipergunakan. Oleh karena itu dapat disimpulkan bahwa mengulang merupakan strategi yang paling lazim dipergunakan dalam mempelajari aksara Han yang baru maupun mengulang materi lama.

\section{Kesulitan Belajar Aksara Han}

Berdasarkan hasil penelitian diketahui bahwa 54,83\% responden mengalami kesulitan dalam menulis aksara Han, 35,48\% responden mengalami kesulitan dalam pelafalan aksara Han dan yang lainnya mengalami kesulitan dalam mengingat arti aksara. Yuan, Xiaojun (2019) menuliskan bahwa orang asing merasa aksara Han sulit dikarenakan pelajar tidak dapat membaca huruf berdasarkan bentuk huruf sebagaimana layaknya huruf latin. Selain itu, aksara Han terkesan seperti gambar yang tidak mempunyai urutan penulisan. Penelitian oleh Gao, Xiaoping (2020) menunjukkan hasil bahwa kesulitan menulis aksara Han menempati posisi ke-7 dan membaca aksara Han berada pada posisi ke-9. Saat responden mengalami kesulitan dalam mempelajari aksara Han, 61,29\% responden akan mempelajari kembali sendiri dengan mengulang dan menghafal, 29,03\% responden bertanya kepada teman atau mencari melalui aplikasi atau kamus elektronik dan hanya 9,68\% responden saja yang berusaha mencari makna aksara, komponen pembentuk aksara, radikal aksara dan urutan penulisan aksara. Dalam penelitian Sy, See \& Abdullah, Arifuddin (2014) diketahui bahwa untuk mengatasi kesulitan belajar bahasa Mandarin 44,6\% responden meminta bantuan teman sekelas dan $43,2 \%$ responden memilih untuk mencari solusi sendiri.

Setelah mempelajari kosakata dalam suatu bab, dosen biasanya akan memberikan dikte kepada responden untuk menguji kemampuan responden dalam menyimak dan 
menuliskan aksara yang didiktekan tersebut. $48 \%$ responden memerlukan 2 jam-1 hari untuk mempersiapkan diri, $65 \%$ responden memerlukan waktu 1-7 hari, sedangkan 19\% responden tidak memiliki kepastian waktu dalam mempersiapkan diri, terkadang waktu yang dibutuhkan singkat namun terkadang pula membutuhkan waktu yang agak panjang.

Namun, hal yang sangat disayangkan adalah 93,54\% responden tidak mengingat dengan baik aksara yang dipelajari setelah dikte selesai. Aksara yang mudah dilupakan oleh responden adalah aksara yang jarang digunakan, goresannya banyak, strukturnya rumit dan disusun dari banyak komponen aksara. Aksara yang lebih mudah diingat oleh responden adalah aksara yang sering/lazim digunakan atau telah dipelajari berulang-ulang, memiliki goresan yang sedikit, berada di urutan atas pada daftar kosakata, atau hubungan arti dan radikalnya sangat erat. Untuk mempelajari kembali aksara yang terlupakan tersebut, $80,64 \%$ responden memilih untuk mengulang kembali materi dan latihan dengan cara menghafal dan menuliskan kembali aksara Han tersebut, sedangkan responden lainnya memilih untuk belajar melalui aplikasi atau bertanya kepada teman.

\section{SIMPULAN}

Penelitian terhadap mahasiswa responden mendapatkan hasil bahwa kesulitan dalam mempelajari aksara Han menempati posisi ketiga setelah kesulitan dalam pelafalan dan penguasaaan kosakata. Belum semua responden memahami jenis-jenis goresan dalam aksara Han, dan hanya 61,29\% responden yang mampu menulis aksara Han sesuai dengan urutannya. Selain itu, responden merasa semakin banyak aksara yang mereka pelajari, kesulitan dalam mempelajari aksara Han semakin tinggi.

Strategi yang digunakan responden untuk mempelajari aksara Han secara berturut-turut adalah menuliskan kembali aksara Han berulang-ulang, belajar dengan menggunakan aplikasi, mengingat urutan penulisan dan mengingat komponen aksara, serta mengingat aksara berdasarkan radikal. Hasil penelitian ini menunjukkan kesamaan dengan hasil penelitian sebelumnya, dimana strategi pembelajaran aksara Han yang paling lazim digunakan pelajar bahasa Mandarin adalah berlatih menuliskan kembali aksara yang dipelajari berulang-ulang. Strategi mengingat komponen aksara dan mengingat aksara berdasarkan radikal juga digunakan oleh responden dalam penelitian Huang, Jinjin (2000) dan Sung, Koyin\&Wu, Hsiaoping (2011) serta Gao, Xiaoping (2020). Untuk mempelajari aksara baru, sebagian responden menggunakan strategi mengulang dan menghafal. Pengulangan dilakukan dengan menggunakan materi di buku, mencari video tutorial, mencatat, latihan membaca, menuliskan kembali berulang-ulang, memperhatikan dan merangkum perbedaan antara dua aksara yang bentuk atau pelafalannya mirip, mengingat radikal dan goresannya dan mencari dahulu artinya baru menghafalkan. Dengan demikian dapat kita lihat bahwa responden mulai menggunakan 
kemajuan teknologi dan informasi dalam pembelajaran aksara Han. Pemakaian aplikasi dan media belajar online lainnya memberikan kemudahan dan akses yang lebih luas bagi pelajar bahasa Mandarin terhadap sumber belajar. Sikap positif responden dalam mencari solusi atas kesulitan yang dihadapi saat mempelajari aksara Han juga menunjukkan motivasi yang cukup kuat untuk menguasai aksara Han. Lebih dari 70\% responden memeriksa kembali aksara Han yang ditulisnya untuk memastikan bahwa aksara tersebut telah ditulis dengan benar. Apabila ditemukan kesalahan penulisan, responden akan segera memperbaikinya.

Meskipun sebagian besar responden telah berusaha menulis aksara Han sesuai dengan urutannya dan menulis dengan rapi, namun masih saja ada responden yang menganggap bahwa asalkan aksara dapat dibaca, maka kerapian dapat diabaikan. Hal ini kurang tepat karena aksara Han perlu ditulis secara simetris agar sesuai dengan strukturnya. Goresan dalam aksara Han yang terlalu pendek atau panjang dapat mengubah arti aksara tersebut atau menimbulkan kesalahan, contohnya aksara 末 dan 未 memiliki pelafalan dan arti yang berbeda.

Kesulitan yang paling besar dalam mempelajari aksara Han adalah menulis. 93,54\% responden tidak mengingat dengan baik aksara Han yang telah didiktekan setelah dikte berakhir, terutama pada aksara yang jarang digunakan atau aksara dengan komponen dan goresan yang banyak serta struktur yang rumit. Hal ini disebabkan oleh tiga hal yaitu responden belajar hanya saat dikte saja, waktu berlatih yang relatif singkat dan ketergantungan pada pinyin yang cukup tinggi. Strategi membaca atau melafalkan hanya digunakan oleh sebagian kecil responden karena responden terbiasa menggunakan bahasa Indonesia, yang pelafalannya berbeda dengan pelafalan dalam bahasa Mandarin.

Berdasarkan analisis diatas, pengajar bahasa Mandarin terutama pengajar mata kuliah aksara Han perlu memaparkan karakteristik aksara Han terutama yang berkaitan dengan radikal, metode pembentukan aksara Han dan komponen aksara yang dapat menyiratkan arti dan bunyi (pelafalan). Dengan memahami karakteristik aksara Han tersebut, mahasiswa akan lebih mudah mengingat, membaca, menuliskan kembali dan memahami arti aksara yang telah dipelajari, contohnya radikal $;$ menyiratkan arti "air". Aksara yang salah satu komponennya menggunakan radikal ini, mempunyai arti berkaitan dengan air, misalnya 清 (jernih), 河 (sungai), 江 (sungai), 池 (sumur)， 液 (cairan). Pada sebagian aksara Han, ada pula sebagian komponen yang dapat menyiratkan bunyi/pelafalan, misalnya 青 (qīng), 清(qīng), 请(qǔng), 情(qíng), 晴(qíng). Menuliskan kembali aksara Han secara berulang-ulang akan lebih efektif apabila responden memahami arti atau pelafalan aksara tersebut. Ketepatan pemilihan dan penggunaaan strategi belajar dapat 
meningkatan efektitivas dan efisiensi waktu dalam pembelajaran aksara Han.

\section{DAFTAR RUJUKAN}

Bie, Hongying, Huang, B. \& Wang, L. 2018. 国际汉语教学汉字教学方法与技巧 Pembelajaran Bahasa Mandarin Internasional-Metode dan Teknik Pengajaran Aksara Mandarin. Beijing: Language and Culture University Press.

Chen, Xi. 2001. 汉字演化说略 Sinopsis Evolusi Aksara Mandarin. Beijing: Qunyan Press.

Chen, Xuechao. 2011. 华文教学法Teaching Method of Chinese Language. Shaanxi: Shaanxi Normal University General Publishing House Co.Lnd.

Gao, Xiaoping. 2020. Australian Students' Perceptions of the Challenges and Strategies for Learning Chinese Characters in Emergency Online Teaching. International Journal of Chinese Language Teaching, Vol 1 (1), P83-98.

Hu, Wenhua. 2008. 汉字与对外汉字教学 Hanzi dan Pengajaran Aksara Mandarin Untuk Siswa Asing. Shanghai: Xuelin Press.

Huang, Borong \& Li, W. 2014. 现代汉语 Bahasa Mandarin Modern. Beijing: Peking University Press.

Huang, Jinjin. 2000. 德国学生学习汉字的情 况及其学习策略 Kondisi dan Strategi Pembelajaran Aksara Mandarin Pada Siswa Kewarganegaraan Jerman. 语言研 究特刊 2000, p. 323-27. 武汉: 国际汉语教学学术研讨会论文集。 中德双方合作研究计划人员交流, PPP 计划编号: 8801-ppp-19.

Huang, Weijia. 2011. 现代汉语文字答问 Question and Answer on Chinese
Character. Beijing: Peking University Press.

Jiang, Xin \& Zhao, G. 2001. 初级阶段外国留 学生汉字学习策略的调查研究 Penelitian Tentang Strategi Belajar Aksara Han pada Mahasiswa Luar Negeri Tingkat Dasar. China Academic Journal Electronic Publishing House, Edisi ke-4, P1017.

Jiang, Xin. 2000. 汉语作为第二语言学习策 略研究 Penelitian Tentang Strategi Belajar Bahasa Mandarin Sebagai Bahasa Kedua. Language Teaching and Linguistic Studies Jornal, Vol 1, P61-68.

Ke, Chuanren. 2018. The Routledge Handbook of Chinese Second Language Acquisition. USA: Routledge CRC Press.

Li, Xiangping. 2012. 汉字理论与应用 Teori dan Praktek Aksara Mandarin. Guangzhou: Jinan University Press.

Liu, Songhao. 2013. 第二语言习得导论—— 对外汉语教学视角 Panduan Akuisisi Bahasa Kedua-Dari Sudut Pandang Pembelajaran Bahasa Mandarin Sebagai Bahasa Kedua. Beijing: World Book Inc.

Sung, K. Y., \& Wu, H. P. 2011. Factors influencing the learning of Chinese characters. International Journal of Bilingual Education and Bilingualism, 14(6), P683-700.

Sy, See \& Abdullah, Arifuddin. 2014. Learners' Attitudes, Perceptions, and Efforts Towards Mandarin As a Foreign Language Course. Journal of Arts, Science \& Commerce, Vol. $\mathrm{V}(4), \mathrm{P} 38-47$.

Zhang, Hesheng. 2013. 汉语可以这样教—— 语言要素篇 Bahasa Mandarin Dapat Diajarkan Dengan Cara Ini-Edisi Pengetahuan Bahasa. Beijing: The commercial Press. 
Zhao, Guo \& Jiang, Xin. 2002. 怎么样的汉字 学习策略最有效? - - 对基础阶段 学生的一次调查研究 Strategi Belajar Aksana Han yang Bagaimana yang Paling Efektif?Suatu Penelitian Dasar Pada Mahasiswa Asing Tingkat Dasar. 语 言文字应用 Vol 2, Applied Linguistic, P79-85.

Zhou, Jian (2009) 汉字教学理论与方法 Teori dan Metode Pengajaran Aksara Mandarin. Beijing: Peking University Press.

Website:

https://en.wikipedia.org/wiki/Chinese charact er_classification, Klasifikasi Aksara Mandarin, diperbaharui 5 January 2020, pada pukul 03:36 (UTC), diakses 11 April 2020.

https://id.wikipedia.org/wiki/Aksara, Aksara Mandarin, diperbaharui 22 Maret 2020, pukul 19.18, diakses 11 April 2020. 